\title{
Assessment of the Impact of Globalization on the Development of the Russian Transport System
}

\author{
Victor Podsorin ${ }^{1, *}$, Elena Ovsiannikova ${ }^{1}$ \\ ${ }^{1}$ Russian University of Transport RUT (MIIT), Institute of Economics and Finance, Department of \\ Economics and Transport Management, 9b9 Obrazcova Ulitsa, Room 1301, Moscow 127994
}

\begin{abstract}
.
Research background: The article describes the main trends in the globalization of economic processes, analyses the economic situation of world commodity markets, considers factors that influence the development of the transport system of Russia, defines the transport component in the cost of bulk cargo transported by Russian railways, presents a conceptual model of its formation for the purpose of improving tariff policy and competitiveness. A study of the dynamics of market conditions helps to identify factors that increase the efficiency of interaction between cargo-forming enterprises and organizations with the transport complex, develop and justify a system of measures to increase the efficiency of the transport system and ensure the sustainability of the national economy, as well as identify factors that contribute to globalization and the integration of production processes of transnational structures into the world economic system.

Purpose of the article: To develop a methodological approach to assessing the impact of global commodity markets in the context of the globalization of economic processes on the development of the transport system of Russia.

Methods: Analysis, classification, deduction, economic and mathematical modelling.

Findings \& Value added: The developed conceptual model for assessing the impact of global commodity markets in the context of the globalization of economic processes on the development of the country's transport system contributes to the improvement of the tariff policy in the field of freight transportation, creates favourable conditions for increasing freight volumes for both transit and export-import cargoes.
\end{abstract}

Keywords: conjuncture of the transport market; conjuncture of world commodity markets; transport component; competitiveness; globalization.

JEL Classification: C55; E32; F01; F63; L91

\footnotetext{
*Corresponding author: podsorin@mail.ru
} 


\section{Introduction}

The transport complex work is vital for the functioning of any country. Transport meets the needs of people in the movement and provides general conditions of production, economic relations between producers and customers; economic relations between countries, republics, territories, regions.

The following general indicators characterize the operation of transport in the system of state statistics (table 1).

Table 1. General transport performance indicators. [1]

\begin{tabular}{|c|c|c|c|c|c|}
\hline Indicator & 2005 & 2010 & 2015 & 2016 & 2017 \\
\hline Cargo turnover, billion tkm & 4676 & 4752 & 5108 & 5198 & 5488 \\
\hline $\begin{array}{l}\text { Passenger turnover, billion } \\
\text { pkm }\end{array}$ & 473,2 & 483,7 & 529,7 & 519,4 & 560,2 \\
\hline $\begin{array}{c}\text { Share of paid transport } \\
\text { services to the population in } \\
\text { the total volume, } \%\end{array}$ & 21,5 & 19,0 & 18,4 & 19,7 & 20,1 \\
\hline $\begin{array}{c}\text { Average annual number of } \\
\text { transport workers, million } \\
\text { people. }\end{array}$ & 3,2 & 2,8 & 2,8 & 2,7 & 2,7 \\
\hline $\begin{array}{c}\text { Share of transport workers in } \\
\text { the economically active } \\
\text { population, } \%\end{array}$ & 6,6 & 6,1 & 6,1 & 6,1 & 7,0 \\
\hline $\begin{array}{c}\text { Investments in fixed assets of } \\
\text { transport organizations, billion } \\
\text { rubles }\end{array}$ & 688,7 & 2071,1 & 2143,6 & 2416,3 & 2240,6 \\
\hline $\begin{array}{l}\text { Share of investments in fixed } \\
\text { assets of transport } \\
\text { organizations in the general } \\
\text { structure of investments in } \\
\text { fixed assets of Russian } \\
\text { enterprises }\end{array}$ & 19,1 & 22,6 & 15,5 & 16,4 & 18,3 \\
\hline $\begin{array}{c}\text { Cost of fixed assets of } \\
\text { transport organizations, billion } \\
\text { rubles }\end{array}$ & 3812,1 & 8633,2 & 14660,5 & 15905,9 & 17421,1 \\
\hline $\begin{array}{c}\text { Share of fixed assets in the } \\
\text { total value of fixed assets of } \\
\text { Russian enterprises }\end{array}$ & 16,7 & 18,4 & 16,5 & 15,8 & 16,0 \\
\hline $\begin{array}{c}\text { Net financial result of } \\
\text { transport organizations, billion } \\
\text { rubles }\end{array}$ & 5,2 & 7,0 & 2,0 & 6,9 & 10,3 \\
\hline
\end{tabular}

The volume of transport organizations work increased from 2005 to 2017 . The growth rate in the average cargo turnover was $1.0-1.3 \%$ per year and in 2019 , the cargo turnover exceeded 5.67 trillion. tonne kilometers $(\mathrm{tkm})$. On average, the growth rate for passenger traffic was 2-2,5\% per year and in 2019, passenger traffic reached the level of 635.2 billion passenger kilometers $(\mathrm{pkm})$. These data indicate a significant role of transport in the country's economy. The transport share of paid services in total volume is more than $20 \%$. The average annual number of employees of the transport is about $3.5 \%$ of the active population of Russia. The share of fixed assets of the transport companies in the general 
structure of fixed assets is more than $16 \%$. The proportion of investment in fixed capital of transport companies in the overall structure of the investment is around $18 \%$.

A positive trend in the transport industry development is the growth of the net financial result of transport companies. Before 2015, there were multidirectional trends of its growth and decline, and after 2015, there was a growing trend. In 2017, the net financial result of transport companies amounted to more than 10 billion rubles. In 2017, the volume of investments in fixed assets of transport companies amounted to more than 2.2 trillion rubles, more than 3.3 times compared to 2005. At the same time, in 2019, this indicator has grown and exceeded 2.5 trillion rubles. Such a large volume of investment in fixed assets of transport companies in comparison with other sectors of the economy characterizes the activation of investment activity in this area.

\section{Methods}

Effective development of the Russian transport complex in the framework of interaction between commodity-forming enterprises and transport companies can be achieved by balancing the size of the transport component, which reflects in the cost of any product.

Based on the study of domestic transport scientists works [2] Russian and foreign researchers a conceptual model of interaction between the processes of globalization and the development of the transport system is developed (figure 1).

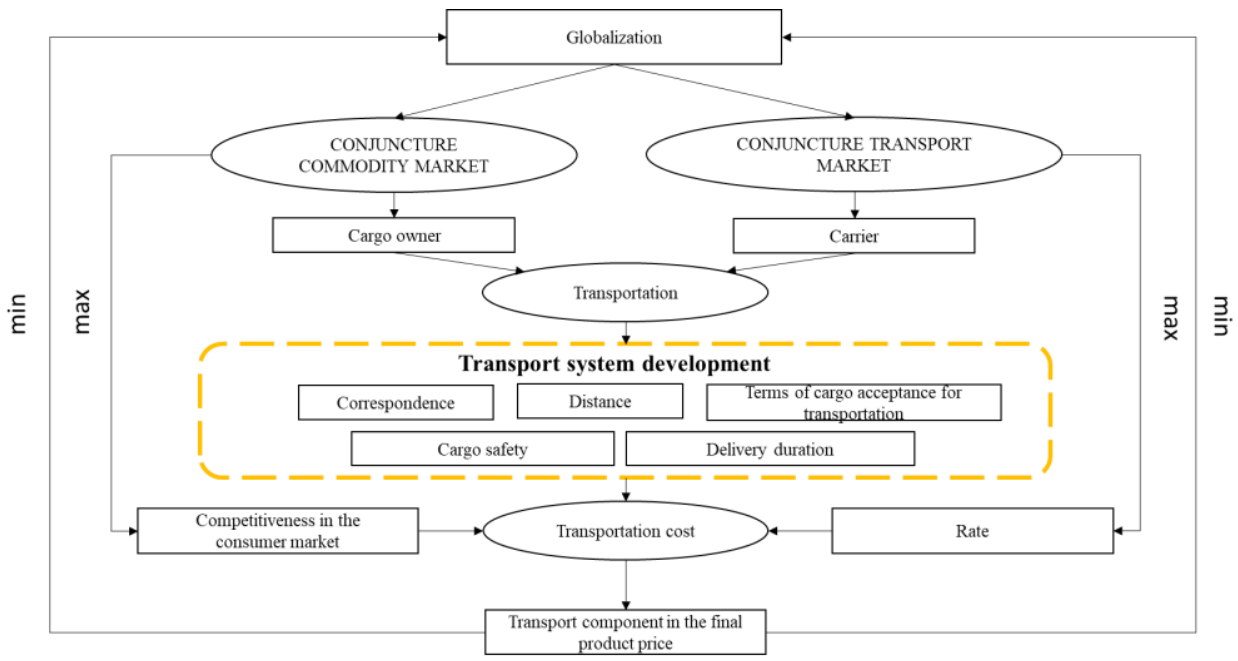

Fig. 1. Conceptual interaction model between the processes of globalization and the transport system development.

It necessary to emphasize that transport product is transportation that cannot be produced in stock. The production and sales (consumption) coincide; the increase in the volume of production of transport products is based on a compromise between the cargo owner and the carrier, expressed in the transport component.

Despite the transport services elements (packaging and storage of goods in a warehouse, loading and unloading operations mechanization, transport documents registration, cargo insurance, calculation and collection of transportation fees based on current tariffs, etc.), which are usually included in the cost of cargo transportation, first of all, the cost of transportation (transport component), is more affected by the tariff rates regulated by the state. 
The traffic volume growth increases the transport companies' revenues, slowly increases operating costs, and reduces the cost of transportation, which has a positive impact on the amount of profit and profitability.

Figure 2 shows the scheme for assessing the impact of commodity market conditions on the tariff policy improvement.

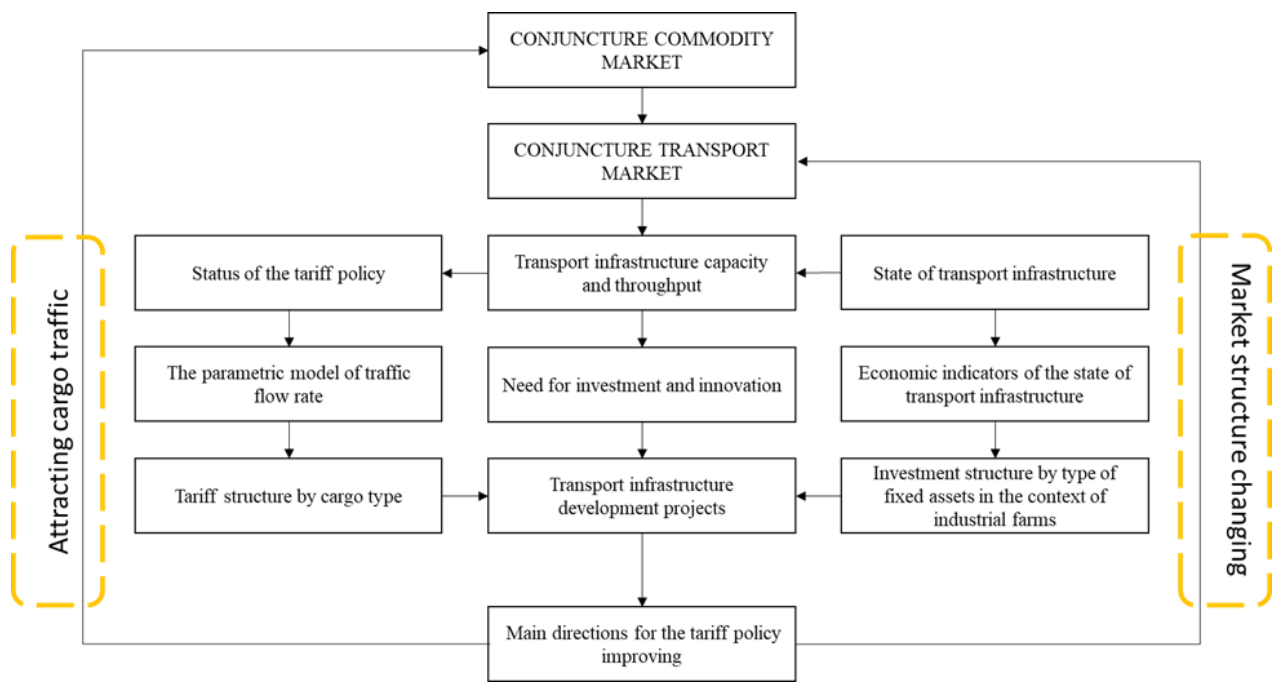

Fig. 2. Impact of commodity market conditions on tariff policy improvement processes.

This diagram shows the principal relationship between the situation on commodity markets and the transport market and their influence on the mechanisms of tariff policy formation in the field of freight transport. The tariff policy improving, taking into account these mechanisms creates favorable conditions for increasing the volume of transportation of main types of goods to their places of consumption. The paper pays close attention to the causal relationships between the organizational configurations of global production networks and uneven development, which leads to uneven development and significant fluctuations in commodity markets and influence on the conjuncture of commodity markets $[3]$.

Under the definition of Dr. D. A. Macheret, the transport market situation is "a situation that has developed in a given time, characterized by a set of indicators, such as the volume and structure of transportation; the level of the rates; costs, income, profit and profitability of transport enterprises; employment, productivity and level of wages in transport; the use of traffic and carrying capacity of highways; the stock of transport enterprises and the level of dividends, etc." [4]

A detailed study of the transport market situation allows to:

- optimize the efficiency of technology and logistics operations;

- improve the performance of technical systems and the efficiency of production resources usage;

- minimize resource costs and production losses;

- improve the assessing competitiveness objectivity in the transport services market;

- specify the dynamics and nature of changes in prices, market capacity, production, and consumption, etc.

The basis of the Russian transport system is railway transport, which performs the major share (more than 46\%) of the total cargo turnover (excluding pipeline transport $87.4 \%$ ). Dynamics of railway freight turnover in recent years has tended to increase, except for a slight decrease in 2013 due to the unfavorable global economic environment. Thus, in 
2018, cargo turnover amounted to 2597 billion tkm, which is almost $30 \%$ higher than in 2010. In turn, the volume of cargo transportation increased by 83.8 million tons since 2010 and had an increase of $7 \%$ in 2018 , but the dynamics over 8 years was mixed uncertain [5, $6]$.

Important characteristics of Railways that determine the possibility of attracting cargo flows are the throughput and carrying capacity. These indicators are a limiting framework for the growth of the transport market in the rail transport segment. Topical issues [7] of investment management for the implementation of the Long-Term Development Program of Russian Railways until 2025 are discussed in the article. It is proposed to use game simulation modelling for an investment plans' development in the context of limited investment resources. This raises the problem of assessing the impact of infrastructure development on the transport component in the final product price. In [8] paper various kinds of external and internal drivers of transport infrastructure growth in the recent decades are considered in the context of globalization's current stage. It is obvious that the transport component changes when market conditions change.

The level of the transport component is estimated on the weighted average fare and the weighted average price. Thus, according to 2018 data, with an average tariff rate of 0.56 rubles/ton, a transportation distance of $2013.73 \mathrm{~km}$, and a cargo turnover of 2596.9 billion tkm, loading of 1289.6 million tons, taking into account the weighted average price of $5026.4 \mathrm{rubles} / \mathrm{km}$, the size of the transport component is $22.44 \%$.

With unchanged parameters such as the transportation range, the weighted average price, the share of dependent expenses, and others, in the context of a decrease in market conditions by $3 \%$ from the current situation and the volume of cargo transportation by 23.2 million tons, the tariff rate increased by $0.007 \mathrm{rubles} / \mathrm{km}$. It led to an increase in the transport component by $0.28 \%$. Under conditions of an increase in the growth rate of traffic by $1 \%$, the tariff rate decreased by $0.0002 \mathrm{rubles} / \mathrm{km}$, which led to a decrease in the transport component by $0.01 \%$. With a change in market conditions by $2-10 \%$ and an increase in the cargo transportation volume from 15.5 million to 77.4 million tons, respectively, there is a significant reduction in the tariff rate by $0.003-0.02$ rubles $/ \mathrm{km}$ and the transport component by $0.14-0.81 \%$.

The time-dependent vehicle routing problems have lately received great attention for logistics companies due to their crucial roles in reducing the time and economic costs. However, the dynamic routing environment and traffic congestions have made it challenging to make the actual travelling trajectory optimal during the delivery process. The objective of the proposed model is to minimize the travelling time and path length of the vehicle, which are the popular indicators in path optimization [9].

The study of the dependence level of a transport component in the final price of transported goods from the index market will allow:

- to assess the impact of globalization on the competitiveness of transport in freight traffic through the traffic change due to changes in commodity markets;

- increase the competitiveness of the entire logistics chain of goods delivery by balancing the transport component;

- to develop an incentives system for the transport system development depending on commodity markets and its changes under the influence of globalization processes;

- to ensure rational distribution of traffic flows, taking into account the optimization of the Russian transport system (in the presence of alternative routes of delivery);

- to form a methodological basis to assess the impact of innovative development projects of transport complex on the transport component in the final product price. 


\section{Results}

The study of the commodity market dynamics helps to identify factors that increase the efficiency of interaction between cargo-Forming enterprises and organizations with the transport complex, improve the transport efficiency, ensure the national economic stability, and accelerate the globalization and integration of production processes of transnational structures.

Insufficient development of the transport complex hurts cargo and passenger transportation. There are difficulties in building long-term and profitable relationships with manufacturing enterprises, as well as in ensuring the full efficiency of bulk cargo transportation. For passengers, the society's need for high - quality and high-speed transportation is not satisfied. Important characteristics of Railways that determine the possibility of attracting cargo flows are the throughput and carrying capacity. These indicators are a limiting framework for the growth of the transport market in the rail transport segment.

The cost of transportation, and, accordingly, the transport component in the price of final products, is more affected by tariff rates. The growth in traffic volume increases the revenues of transport companies, slowly increases operating costs, and reduces the transportation cost, which has a positive effect on the amount of profit and profitability. For example, increasing commodity markets in transport costs for $10 \%$ reduces by $0.81 \%$, while reducing the market conditions by $3 \%$, transport costs increase by $0.28 \%$.

The developed scheme for assessing of commodity market conditions impact in the context of globalization on the improving tariff policy processes reflects the fundamental relationship between the situation of commodity markets and the transport market, as well as the impact of the commodity markets dynamics on the mechanisms of tariff policy formation in the field of freight transport. Improving the tariff policy, taking into account these mechanisms, creates favorable conditions for increasing the volume of transportation of main types of goods to their places of consumption.

The main trends in the globalization impact on the development of the Russian transport system are:

- government spending on transport infrastructure growing more slowly than announced in the program of transport complex development;

- lack of full implementation of transport projects, which limits the development of commodity markets;

- reduced the amount of direct government support in the implementation of large transport projects;

- development of transport infrastructure limits the development of commodity markets that has an impact on the development prospects of other sectors of the economy;

- the volume of direct state support for major transport projects is decreasing;

- the development of transport infrastructure restricts the development of commodity markets, which affects the prospects for the development of other economic sectors;

- the disproportionality of transport infrastructure development across regions reduces the mobility of the economy business sector, while the localization of large-scale development projects further aggravates the uneven transport provision of the country's territories.

\section{Discussions \& Conclusions}

Scientific circles are actively discussing globalization processes. The article [10] assesses the impact of globalization on the transport system development, which in turn significantly affects the environment. As usual, the impact is evaluated at two levels: impact during 
operation (usage) related to a chosen operational unit; the life cycle (project life-cycle) impact. The environmental impact is characterized by the chemical and noise emissions.

Study [11] determines the dynamic linkages between globalization, financial development and carbon emissions in Asia Pacific Economic Cooperation (APEC) countries in the presence of energy intensity and economic growth under the framework of Environment Kuznets Curve (EKC). Empirical results indicate that globalization and financial development significantly reduce carbon emissions, but economic growth and energy intensity increase them.

The logistics sector of transport services under the influence of globalization is developing a new approach. For evaluation of the duration of delivery "Just-In-Time" (JIT) will improve the efficiency of supply chains in accordance with one of the major criteria, namely customer satisfaction [12].

The logistics industry is a critical economic component in most countries and has a significant impact on their citizens' quality of life. No single solution will address all of these issues; however, horizontal collaboration appears to offer an opportunity to take a significant step in the right direction. There is an abundance of opportunities for logistics service providers to collaborate, but there is little effective collaboration in practice, and the issues related to this gap remain largely unexplored by academic researchers. This paper offers a review of the existing research in horizontal collaboration, specifically highlighting efforts focussed in the areas of on-demand logistics, freight consolidation, facility sharing, incentives, case studies, and quantitative analyses [13].

For the complete satisfaction of the population and the economy in transportation in full, all modes of transport interact and compete with each other, performing their functions. At the same time, each type of transport has its advantages and disadvantages, which requires studying the economic factors of their development.

Transport activities are closely linked to the state of the Russian economy and industry. The quality and quantity of transport performance depend on the commodity markets state that forms the main products for transportation, and the transport performance, in turn, determines the production relationship between cargo-forming enterprises and the consumer sector.

The study of market dynamics helps to identify factors that increase the interaction efficiency between industrial enterprises and organizations with the transport complex. It improves the railway transport efficiency, ensures the national economic stability, and accelerates the globalization and integration of production processes of transnational structures. The article [14] claims that larger firms possess better knowledge of market conditions in foreign countries, even when those firms have not exported in the past. The complexity of the economic assessment of the market dynamics impact on these factors lies in the absence of direct functional links between the considered parameters of the formation of results. In paper [15], a holistic hierarchical analytical model is proposed to assess the performance of enablers in an integrated logistics system. Due to the ambiguous and complex environment, various refinements are needed to assess enablers and prioritize for the criteria such as economic, operational, and environment.

The result that helps to maximize the competitiveness and investment activity of industrial enterprises, large shippers that own their rolling stock, operators, and captive companies, is possible by reducing the price of transportation, namely, a discount on the tariff. Large reduction in import tariffs in a customer industry induces suppliers to choose more conservative financial policies [16]. In turn, the increasing volume of product sales in the places of their consumption, due to the increase in cargo flows, effectively adds up for the transport complex. On the part of the state, the result is possible by improving the efficiency of the country's economic mechanism, which affects the results of all economic sectors. In paper [17], presents a multi-criteria approach to the problem of selecting 
effective innovative projects and innovative technologies that increase competitiveness in high-tech industries.

The results of research by Russian transport scientists, namely V. G. Galaburda, E. A. Ivanova, V. A. Podsorin, Yu. I. Sokolov, and N. P. Tereshina, have shown that an adequate response to changes in market conditions is a decisive factor in regulating the transportation demand, improving the efficiency of the relationships with customers of transport companies, and increasing the transport companies' profitability [18].

Insufficient development of the transport complex harms cargo and passenger transportation. There are difficulties in building long-term and profitable relationships with manufacturing enterprises, as well as in ensuring the full efficiency of bulk cargo transportation. For passengers, the society's need for high - quality and high-speed transportation is not satisfied $[19,20]$. It follows that all indicators are interrelated, and it is impossible to increase one of them without increasing the others. For example, an increase in traffic volume is impossible without the development of infrastructure, respectively, without increasing the capacity and carrying capacity of highways, which in turn requires great investment.

\section{References}

1. Transport in Russia. 2018: Stat. sat./ Rosstat, Retrieved from: https://www.gks.ru/free doc/doc 2018/transp18.pdf Date of request: 03.09.2020.

2. N.P. Tereshina, V.A. Podsorin. (2016). Economic assessment of investments. [Online] Retrieved from: https://umczdt.ru/shop/ekonomika i upravlenie/tereshina n $\mathrm{p}$ p_pod sorin_v_a i dr_ekonomicheskaya otsenka investitsiy $1 /$

3. Coe, N.M., Yeung, H.W.-C. (2019). Global production networks: Mapping recent conceptual developments. Journal of Economic Geography, 19(4), 775-801.

4. Ryshkov, A.V. (2009). Research of the economic situation of railway transport (methodology, analysis, estimates), [Online] Retrieved from: https://www.dissercat.com/content/issledovanie-ekonomicheskoi-konyunkturyzheleznodorozhnogo-transporta-metodologiya-analiz-ot

5. Annual reports JSCo «RZD» [Online] URL: www.rzd.ru

6. Federal State Statistics Service, [Online] Retrieved from: http://www.gks.ru/free doc /doc 2018/world18.pdf

7. Shkurina, L., Maslova, M., Podsorin, V., Tereshina, N. (2019). Effective investment management with elements of simulation modelling. E3S Web of Conferences, Retrieved from: https://www.scopus.com/record/display.uri?eid=2s2.085076549715 $\underline{\text { \&origin }}=$ resultslist

8. Varnavskii, V.G. (2020). Global transport \& logistics infrastructure. World Economy and International Relations, 64(1), 5-14.

9. Xu, W., Li, J. (2020). A Fissile Ripple Spreading Algorithm to Solve Time-Dependent Vehicle Routing Problem via Coevolutionary Path Optimization, Journal of Advanced Transportation, 8815983

10. Rohacs, J., Rohacs, D. (2020). Total impact evaluation of transportation systems. Transport, 35(2), 193-202.

11. Zaidi, S.A.H., Zafar, M.W., Shahbaz, M., Hou, F. (2019). Dynamic linkages between globalization, financial development and carbon emissions: Evidence from Asia Pacific Economic Cooperation countries. Journal of Cleaner Production, Vol.: 228, 533-543. 
12. Lukinskiy, V., Lukinskiy, V., Merkuryev, Y. (2018). Modelling of transport operations in supply chains in obedience to "just-in-time" conception. Transport, 33(5), 11621172.

13. Ferrell, W. Ellis, K., Kaminsky, P., Rainwater, C. (2020). Horizontal collaboration: opportunities for improved logistics planning. International Journal of Production Research, 58(14), 4267-4284.

14. Dickstein, M.J., Morales, E. (2018). What do exporters know? Quarterly Journal of Economics, 133(4), 1753-1801.

15. Mohanty, M., Shankar, R. (2019). A hierarchical analytical model for performance management of integrated logistics. Journal of Management Analytics, 6(2), 173-208.

16. Huang, Q., Kim, R. (2019). Capital structure decisions along the supply chain: Evidence from import competition. Journal of International Business Studies, 50(6), 873-894.

17. Chursin, A., Vlasov, Y., \& Makarov, Y. (2016). Innovation as a Basis for Competitiveness. Theory and practice (Book), 1-336.

18. N.P. Tereshina, V.A. Podsorin , Yu.I. Sokolov and others. (2019). Economics of railway transport. Retrieved from: http://www.iprbookshop.ru/86683.html.

19. Tereshina N.P., Podsorin V.A., Ovsyannikova E.N. (2020). Development of transport infrastructure in the context of changing economic conditions. Journal of transport, 3 , 6-9.

20. Podsorin V.A., Ovsyannikova E.N. (2019). Development of railway infrastructure in Russia taking into account commodity market conditions. Proceedings of the twelfth international conference Managing the development of large-scale mlsd systems'2019, (pp. 699-702). Moscow. 